\title{
Cinnamic hydroxamic acid inhibits the proliferation of gastric cancer cells via upregulation of miR 145 expression and down-regulation of P13K/Akt signaling pathway
}

\author{
ShanPing Li, SenMao $\mathrm{Hu}^{*}$ \\ Department of General Surgery, Affiliated Renhe Hospital of China Three Gorges University, Yichang, Hubei 443000, China
}

*For correspondence: Email: HoytSerranoxcg@yahoo.com; Tel: 0086-15871569439

Sent for review: 21 December 2019

Revised accepted: 22 April 2020

\begin{abstract}
Purpose: To investigate the anti-proliferative effect of cinnamic hydroxamic acid (CHA) on gastric cancer (GC) cells, and its mechanism of action.

Methods: Two GC cell lines (SGC-7901 and MKN1) and normal human gastric epithelial cells (GES1) were used for this study. The GC cells were cultured in Dulbecco's modified Eagle's medium (DMEM)supplemented with $10 \%$ fetal bovine serum (FBS) and $1 \%$ penicillin/streptomycin solution at $37{ }^{\circ} \mathrm{C}$ for $24 \mathrm{~h}$ in a humidified atmosphere of $5 \% \mathrm{CO} 2$ and $95 \%$ air. GES1 cells were cultured in RPMI medium supplemented with $10 \%$ FBS only. Cell viability and apoptosis were determined using 3 (4,5 dimethyl thiazol $2 \mathrm{yl}$ ) 2,5 diphenyl $2 \mathrm{H}$ tetrazolium bromide (MTT), and flow cytometric assays, respectively. The level of expression of microRNA-145 (miR-145) was determined using real-time quantitative polymerase chain reaction (qRT-PCR). Protein expressions of c-Myc, $p-A K T, P I 3 K, p 21$, and matrix metalloproteinase (MMP)-2 and MMP-9were determined using Western blotting.

Results: Treatment of GC cells with CHA for $72 \mathrm{~h}$ led to significant and dose-dependent reduction in their viability, and significant and dose-dependent increase in the number of apoptotic cells $(p<0.05)$. It also significantly arrested GC cell cycle at G1 phase $(p<0.05)$. The treatment significantly and dosedependently decreased SGC-7901 and MKN1 cell migration and invasion, and upregulated miR-145 mRNA expression $(p<0.05)$. The expression of miR-145 mRNA was significantly higher in MKN1 cells than in SGC-7901cells ( $p$ 0.05). Treatment of SGC-7901 and MKN1 cells with CHA significantly downregulated protein expressions of $c-M y c, M M P-2 / 9, P I 3 K$ and $p-A K T$, but upregulated p21 protein expression $(p<0.05)$.

Conclusion: These results show that CHA inhibits the proliferation of GC cells via upregulation of miR145 expression and down-regulation of P13K/Akt signaling pathway. Therefore, CHA has a good potential as a therapeutic agent for the management of gastric cancer
\end{abstract}

Keywords: Apoptosis, Cinnamic hydroxamic acid, Gastric cancer, Metastasis, Proliferation

This is an Open Access article that uses a fund-ing model which does not charge readers or their institutions for access and distributed under the terms of the Creative Commons Attribution License (http://creativecommons.org/licenses/by/4.0) and the Budapest Open Access Initiative (http://www.budapestopenaccessinitiative.org/read), which permit unrestricted use, distribution, and reproduction in any medium, provided the original work is properly credited.

Tropical Journal of Pharmaceutical Research is indexed by Science Citation Index (SciSearch), Scopus, International Pharmaceutical Abstract, Chemical Abstracts, Embase, Index Copernicus, EBSCO, African Index Medicus, JournalSeek, Journal Citation Reports/Science Edition, Directory of Open Access Journals (DOAJ), African Journal Online, Bioline International, Open-J-Gate and Pharmacy Abstracts

\section{INTRODUCTION}

Gastric cancer (GC), a common digestive tract cancer characterized by high morbidity and mortality, is prevalent among South-East Asians
$[1,2]$. Although there has been a drop in the incidence of GC in recent times, its prognosis remains poor [3]. Early detection is key to the treatment of GC, since late diagnosis is associated with poor prognosis [4]. Cell 
metastasis is responsible for the failure of chemotherapy [5].

MicroRNAs (miRNAs) consist of approximately 19-25 nucleotides and function through basepairing with complementary sequences within mRNA molecules. MicroRNAs influence the expression of target genes by pairing with their 3'UTR regions, thereby participating in life processes such as cell growth and differentiation, and apoptosis $[6,7]$. They have been implicated in the pathogenesis of GC [8]. The expression of miR-145 has been shown to be down-regulated in precancerous lesions of colorectal tissues [9]. Although miR-145 has a tumor-inhibiting effect, the mechanisms underlying its involvement in the proliferation, metastasis, and invasion of tumor cells are not entirely clear. It recruits Myc proto-oncogene protein (c-Myc) and transcription factor-1 (TF-1) in tumor-suppression $[10,11]$. MicroRNA-145 inhibits GC cell proliferation via regulation of myosin $\mathrm{VI}$ (MYO6) expression [12]. Its inhibition of GC cell growth and metastasis has also been reported to occur via suppression of the expressions of specificity protein 1 (Sp1) and N-cadherin [13].

Cinnamic hydroxamic acid (CHA) and its derivatives inhibit the activity of nuclear, as well as cytoplasmic histone deacetylases (HDACs) [14].The presence of para- and metasubstituents in $\mathrm{CHAs}$ make these compounds multi-potent inhibitors, while ortho-substituents give them selectivity as inhibitors of HDACs[15]. Studies have shown that the presence of small groups such as methyl, methoxy, and trifluoromethyl in the aromatic ring of $\mathrm{CHAs}$ reduces the potency of these compounds, while a large substituent like pyridyl4-oxy group increases their activities and selectivity for HDAC inhibition [16]. This study investigated the antiproliferative effect of CHA on GC cells, and the mechanism involved.

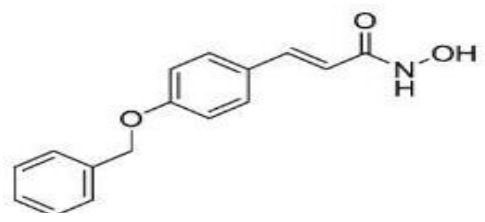

Figure 1: Chemical structure of $\mathrm{CHA}$

\section{EXPERIMENTAL}

\section{Materials}

Flow cytometer and FACScan software were purchased from BD Biosciences (USA). Anti-cMyc, p-AKT, PI3K, p21, MMP-2, MMP-9 and GAPDH polyclonal antibodies were products of
Cell Signaling Technology (USA). Light microscope was obtained from Olympus Corporation (Japan) while RNAiso Plus was purchased from Dalian (China).

\section{Cell culture}

Two GC cell lines (SGC-7901 and MKN1) and normal human gastric epithelial cells (GES1) were obtained from the Chinese Academy of Sciences. The GC cells were cultured in DMEM supplemented with $10 \%$ FBS and $1 \%$ penicillin/streptomycin solution at $37{ }^{\circ} \mathrm{C}$ for $24 \mathrm{~h}$ in a humidified atmosphere of $5 \% \mathrm{CO}_{2}$ and $95 \%$ air. The GES1 cells were cultured in RPMI medium supplemented with $10 \%$ FBS only.

\section{Cell viability assay}

The viability of MKN1 and SGC-7901 cells in the presence of CHA was determined using MTT assay. The cells were seeded at a density of $1 \mathrm{x}$ $10^{5} \mathrm{cells} /$ well in 96-well plates and cultured in DMEM for $24 \mathrm{~h}$. Then, CHA $(0.75-20 \mu \mathrm{M})$ was added to the cells and incubated for $72 \mathrm{~h}$. At the end of the third day, $20 \mu \mathrm{L}$ of MTT solution (5 $\mathrm{mg} / \mathrm{mL}$ ) was added to the wells, followed by incubation at $37{ }^{\circ} \mathrm{C}$ for $2 \mathrm{~h}$. The medium was finally replaced with $120 \mu \mathrm{L}$ of $0.1 \%$ dimethyl sulfoxide (DMSO) to completely dissolve the formazan crystals formed. The absorbance of the samples was read in a microplate reader at 485 $\mathrm{nm}$ after shaking for $15 \mathrm{~min}$. The assay was performed in triplicate. Cell viability (V) was calculated as shown in Eq 1.

$V(\%)=(A t / A c) 100$

where At and Ac are the absorbance of test and control group, respectively.

\section{Assessment of cell apoptosis}

The GC cells were seeded at a density of $1.5 \mathrm{x}$ $10^{5}$ cells/well in 6-well plates and cultured for 24 h. Then, CHA $(3-20 \mu \mathrm{M})$ was added to the medium and incubated for another $48 \mathrm{~h}$, followed with washing in phosphate-buffered saline (PBS), and thoroughly mixing with $300 \mu \mathrm{L}$ binding buffer. The cells were then stained with $5 \mu \mathrm{L}$ each of annexin V-fluorescein isothiocyanate (FITC) and propidium iodide $(\mathrm{PI})$ within $20 \mathrm{~min}$ at room temperature in the dark. Cell apoptosis was determined using a flow cytometer fitted with argon laser operated at $485 \mathrm{~nm}$.

\section{Cell cycle analysis}

The effect of $\mathrm{CHA}$ on cell cycle distribution in GC cells was determined using a flow cytometer. The 
GC cells treated with varied concentrations of CHA $(3-20 \mu \mathrm{M})$ were seeded into 6 -well plates and incubated for $48 \mathrm{~h}$. The cells were then washed with PBS, and fixed with $70 \%$ ethyl alcohol at $-30 \quad{ }^{\circ} \mathrm{C}$ overnight. Then, tris-hydrochloride buffer ( $\mathrm{pH} 7.4$ ) containing $1 \%$ RNase A was added to the plates. The cells were subsequently stained with $\mathrm{PI}(5 \mathrm{mg} / \mathrm{mL})$ and injected into the flow cytometer for analysis.

\section{Determination of cell invasiveness}

The degree of invasiveness of GC cells was determined using Transwell invasion assay. Cells treated with varied concentrations of $\mathrm{CHA}(3-20$ $\mu \mathrm{M})$ for $48 \mathrm{~h}$ in RPMI-1640 medium were seeded at a density of $1 \times 10^{5}$ cells/well in Transwell chamber coated with substrate $(200 \mathrm{mg} / \mathrm{mL}$ Matrigel) and cultured in serum-free medium. Medium containing $20 \%$ FBS was added to the lower chamber. After $24 \mathrm{~h}$, the cells that passed through the matrix gel membrane were stained with crystal violet after fixation, photographed and counted using an inverted microscope.

\section{Cell migration assay}

The migratory ability of GC cells was determined using scratch test. Cells in logarithmic growth phase were seeded in 6-well plates until they attained 90 - $100 \%$ confluency, and scratches were made on the cell monolayers. After washing thrice with serum-free medium, the cells were further cultured for $48 \mathrm{~h}$, and then observed and analyzed using Image Pro Plus (7.0). Cell motility (M) was calculated as shown in Eq 2.

$M(\%)=1-(\mathrm{Sm} / \mathrm{Si}) 100$

where Sm and Si are the scratch width during measurement and initially, respectively.

\section{Western blotting}

The GC cells treated with varied concentrations of CHA $(3-20 \mu \mathrm{M})$ were washed with PBS and lysed with Tris- $\mathrm{HCl}(40 \mathrm{mM}, \mathrm{pH} 7.4)$ containing sodium chloride (150 mM), Triton X-100 (1\%v/v), and protease inhibitors. The resultant lysate was centrifuged at $15000 \mathrm{rpm}$ for $15 \mathrm{~min}$ at $4{ }^{\circ} \mathrm{C}$, and the protein concentration of the supernatant was determined using bicinchoninic acid (BCA) protein kit. A portion of total cell protein $(40 \mu \mathrm{g})$ from each sample was separated on $12 \%$ sodium dodecyl sulphate (SDS)-polyacrylamide gel electrophoresis and transferred to a fixed polyvinylidene fluoride membrane at $110 \mathrm{~V}$ and $90^{\circ} \mathrm{C}$ for $120 \mathrm{~min}$.
Subsequently, skimmed milk (5 \%) in Trisbuffered saline containing $0.1 \%$ Tween-20 (TBS$\mathrm{T})$ was added with gentle shaking at $37^{\circ} \mathrm{C}$, and incubated for $2 \mathrm{~h}$ to block non-specific binding of the blot. Incubation of the blots was performed overnight at $4{ }^{\circ} \mathrm{C}$ with primary antibodies of $\mathrm{C}$ Myc, p-AKT, PI3K, p21, MMP-2, MMP-9 and $\mathrm{GAPDH}$, each at a dilution of 1 to 1000. Then, the membrane was washed thrice with TBS-T and further incubated with horseradish peroxidase-conjugated goat anti-rabbit $\lg G$ secondary antibody for $2 \mathrm{~h}$ at room temperature. The blot was developed using an X-ray film. Grayscale analysis of the bands was performed using image $J(2.0)$. The respective protein expression levels were normalized to that of standard GAPDH.

\section{qRT-PCR}

The level of expression of miR-145 was measured using qRT-PCR. Trizol RNA extraction reagent (RNAiso Plus) was used to extract total RNA from cells in each group, while cDNA synthesis kit (ProSTARt First Strand RT-PCR kit) was used to perform cDNA synthesis reaction according to the instructions of the manufacturer. Light Cycler 1536 RT-PCR detection system was used for the estimation of the mRNA expression of miR-145. Variation in the cDNA content was normalized using GAPDH. The PCR reaction mixture $(20 \mu \mathrm{L})$ consisted of $6.4 \mu \mathrm{L}$ of $\mathrm{dH}_{2} \mathrm{O}, 1.6$ $\mu \mathrm{L}$ of gene-specific primer $(10 \mu \mathrm{M}), 2 \mu \mathrm{L}$ of synthesized cDNA and $10 \mu \mathrm{L}$ of SYBR Premix Ex Taq ${ }^{\mathrm{TM}}$ II. The amplification process consisted of $94{ }^{\circ} \mathrm{C}$ for $3 \mathrm{~min}, 38$ cycles at $94{ }^{\circ} \mathrm{C}$ for $26 \mathrm{~s}, 53$ ${ }^{\circ} \mathrm{C}$ for $26 \mathrm{~s}, 70{ }^{\circ} \mathrm{C}$ for $26 \mathrm{~s}$ and $70{ }^{\circ} \mathrm{C}$ for $5 \mathrm{~min}$. The $\mathrm{Ct}$ value of $\mathrm{U} 6$ was taken as the internal parameter, and $2^{-\Delta \Delta C t}$ was used to calculate the relative expression level of the protein. The sequence of primers used are shown in Table 1.

Table 1: Primer sequence used for qRT-PCR

\begin{tabular}{ll}
\hline Gene & Sequence \\
\hline miR-145 & Forward: 5'-GTC CAG \\
& TTT TCC CAG GAA \\
& TCC CT-3' \\
& Backward: 5'-GCT \\
& GTC AAC GAT ACG \\
& CTA CCT A-3' \\
\hline
\end{tabular}

\section{Statistical analysis}

Data are expressed as mean \pm SD. Statistical analysis was performed using SPSS (17.0). Groups were compared using Tukey's post-hoc test. Statistical significance was assumed at $p<$ 0.05 . 


\section{RESULTS}

\section{Effect of CHA on the viability of GC cells}

As shown in Figure 2, treatment of GC cells with $\mathrm{CHA}$ for $72 \mathrm{~h}$ led to significant and dosedependent reduction in their viability $(p<0.05)$.

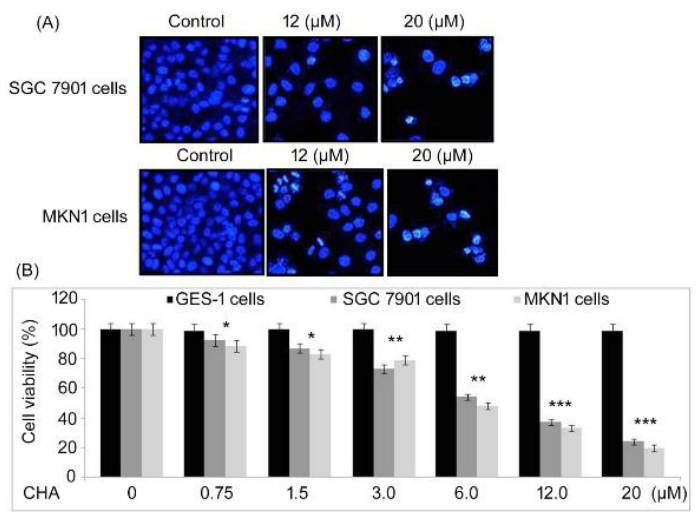

Figure 2: Effect of $\mathrm{CHA}$ treatment on the viability of SGC-7901 and MKN1 cells. (A): Microscopic examination of $\mathrm{GC}$ cell morphology (x250); and (B): results of MTT assay; ${ }^{*} p<0.05,{ }^{* *} p<0.01$ and ${ }^{* * *} p<$ 0.001 , compared with control cells

\section{Effect of CHA on apoptosis of GC cells}

Treatment with CHA significantly and dosedependently promoted apoptosis in GC cells $(p<$ 0.05; Figure 3).

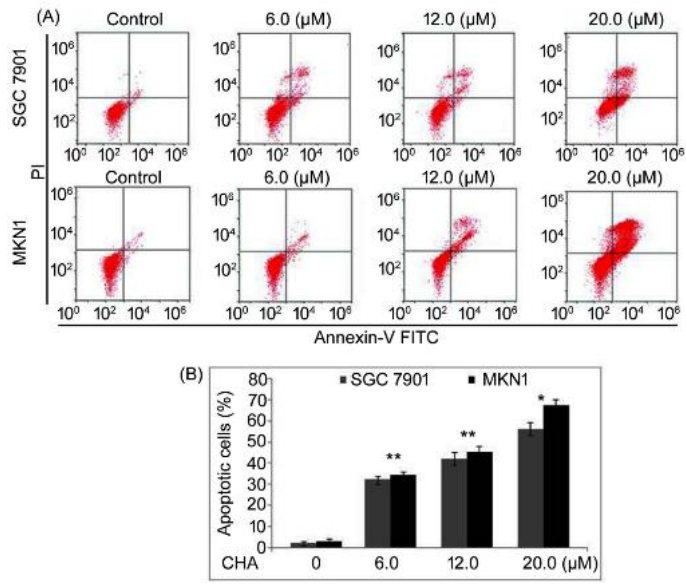

Figure 3: Effect of CHA on apoptosis in SGC-7901 and MKN1 cells. (A): Results of flow cytometric analysis of GC cells; and (B): apoptotic cell population in SGC-7901 and MKN1 cells; ${ }^{*} p<0.05 ;{ }^{* *} p<0.01$, compared with control cells

\section{Effect of CHA on GC cell cycle arrest}

As shown in Figure 4, CHA treatment significantly and dose-dependently increased GC cell population in $\mathrm{G} 1$ phase of the cell cycle, but reduced the cell population in $S$ and $G 2 / M$ phases significantly and dose-dependently $(p<$ 0.05). However, CHA significantly arrested GC cell cycle at G1 phase.
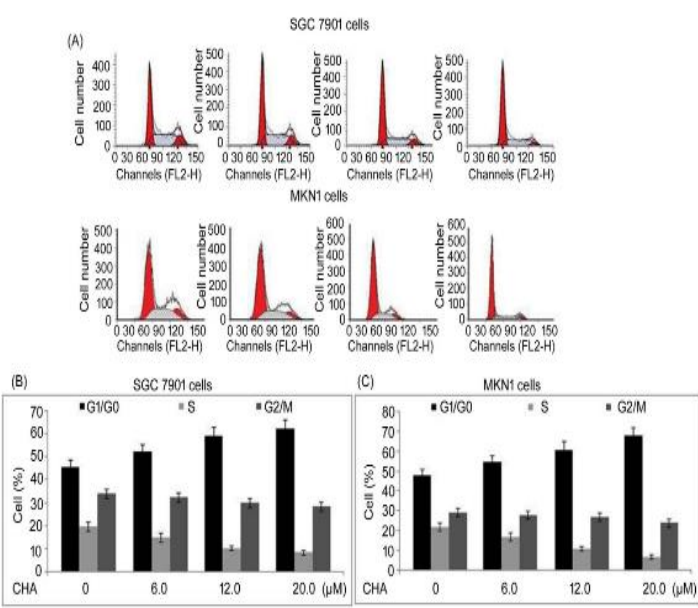

Figure 4: Effect of CHA on GC cell cycle progression. (A): Distribution of cells among different phases of the cell cycle, as measured using a flow cytometer; and (B): Chart showing cell population in various phases of the cell cycle; ${ }^{*} p<0.05 ;{ }^{* *} p<0.01$, when compared with control cells

\section{Effect of CHA on GC cell metastasis in vitro}

Cinnamic hydroxamic acid (CHA) treatment significantly and dose-dependently decreased SGC-7901 and MKN1 cell migration and invasion $(p<0.05)$. These results are shown in Figure 5.

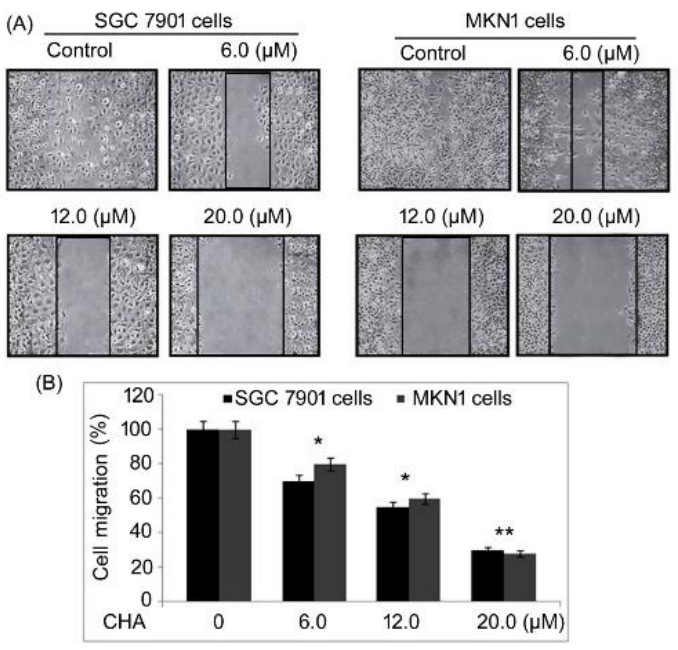

Figure 5: Effect of CHA on migration of SGC-7901 and MKN1 cells. (A): Migration of GC cells as measured using wound healing assay (x250); and (B): chart showing the extent of migration of GC cells; ${ }^{*} p<$ 0.05 and ${ }^{* *} p<0.01$, compared with control cells

Trop J Pharm Res, May 2020; 19(5): 960 

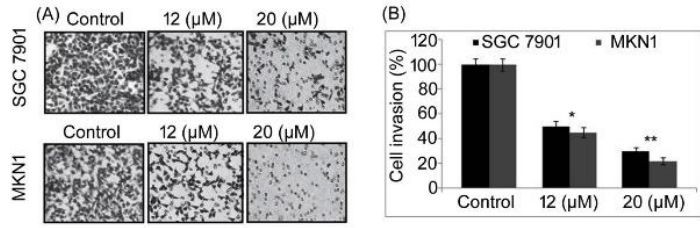

Figure 6: Effect of CHA on SGC-7901 and MKN1 cell invasiveness. (A): Gastric cancer cell invasiveness determined using Transwell assay (x 250); and(B): Chart representing adhesive cell counts; ${ }^{*} p<0.05 ;{ }^{* *} p$ $<0.01$, compared with control cells

\section{Effect of CHA on expression level of miR-145in SGC-7901 and MKN1 cells}

As shown in Figure 7, treatment of GC cells with CHA significantly and dose-dependently upregulated miR-145 mRNA expression $(p<$ $0.05)$. The expression of miR-145 mRNA was significantly higher in MKN1 cells than in SGC-7901 cells $(p<0.05)$.

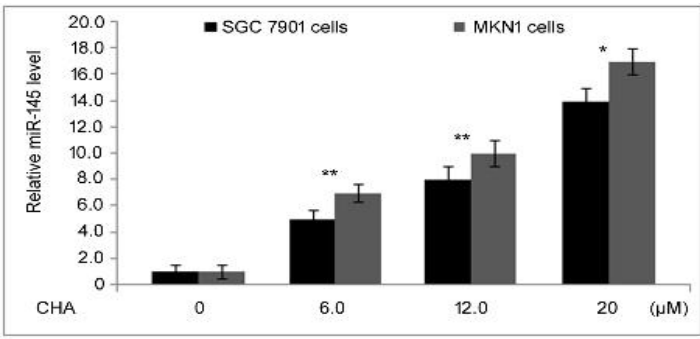

Figure 7: Effect of CHA on miR-145 expressions in SGC-7901 and MKN1 cells. ${ }^{*} p<0.05$ and ${ }^{* *} p<0.01$, compared with control cells

\section{Regulatory effect of CHA on PI3K/AKT pathway}

Treatment of SGC-7901 and MKN1 cells with $\mathrm{CHA}$ significantly down-regulated protein expressions of c-Myc, MMP-2/9, PI3K and $\mathrm{p}$ AKT, but upregulated p21 protein expression, significantly and dose-dependently $(p<0.05$; Figure 8)
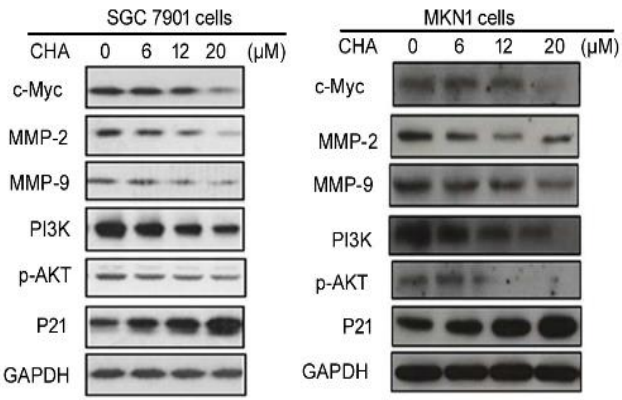

Figure 8: Effect of $\mathrm{CHA}$ on $\mathrm{PI} 3 \mathrm{~K} / \mathrm{AKT}$ signaling pathway

\section{DISCUSSION}

Globally, approximately one million people come down with GC annually [17]. The pathogenesis of $\mathrm{GC}$ is a complex process involving several genes and regulatory pathways. MicroRNAs have been shown to participate in the pathogenesis of GC. However, the precise molecular mechanism involved remains unclear. The initiation of GC involves several signaling pathways and abnormal gene expression patterns which are often accompanied by inactivation of antioncogenes and activation of oncogenes. This study investigated the anti-proliferative effect of CHA on GC cells, and the mechanism involved.

Apoptosis, a physiologically significant process for getting rid of damaged cells from the body of a multicellular organism is usually triggered by many antitumor drugs [18]. Natural compounds such as resveratrol and L-securinine engage multiple mechanisms for induction of apoptosis in tumor cells [19].

In this study, CHA treatment significantly and dose-dependently promoted apoptosis in SGC-7901 and MKN1 cells, and significantly arrested the cells at $\mathrm{G} 1$ phase. The proliferation of SGC-7901 and MKN1 cells was significantly and dose-dependently suppressed by $\mathrm{CHA}$ treatment. These results indicate that $\mathrm{CHA}$ may inhibit the proliferation of GC cells via induction of apoptosis and cell cycle arrest at G1 phase.

Alteration in miRNA expression has been implicated in many disease conditions. Studies have shown that miR-145 expression is significantly down-regulated in many types of cancers, and that it serves as a target for a variety of anticancer drugs [20]. The results of this study showed that miR-145 expression was significantly and dose-dependently downregulated in SGC-7901 and MKN1 cells. These findings are in agreement with those of previous reports [11]. It is likely that the anti-proliferative effect of CHA on GC cells is associated with the upregulation of miR-145 expression.

The PI3K/AKT signaling pathway is a key regulator of normal cellular processes involved in cell growth, proliferation, metabolism, motility, survival, and apoptosis [21]. Aberrant activation of this pathway promotes the survival and proliferation of tumor cells in many human cancers. One of the oncogenes, c-Myc, is associated with cellular transformation and proliferation, as well as regulation of apoptosis [22]. Increased expression of c-Myc leads to DNA damage and ultimately cell apoptosis [23]. Therefore, targeting c-Myc expression 
contributes significantly to arrest of cell cycle progression and inhibition of cell proliferation [24]. In this study, treatment of SGC-7901 and MKN1 cells with CHA led to significant and dosedependent down-regulation of protein expressions of PI3K, p-AKT and c-Myc, an indication that $\mathrm{CHA}$ may serve as a downregulating agent for $\mathrm{PI} / \mathrm{K} / \mathrm{AKT}$ pathway in $\mathrm{GC}$ cells.

Matrix metalloproteinases (MMPs) are a group of enzymes that are collectively responsible for the degradation of most extracellular matrix proteins during organogenesis, growth and normal tissue turnover. Matrix metalloproteinase (MMP)-2 and MMP-9 contribute significantly to the decomposition of type IV collagen, thereby promoting cell migration and invasion [25]. The results of this study indicated that $\mathrm{CHA}$ significantly down-regulated protein expressions of MMP2 and MMP9 in SGC-7901 and MKN1 cells, an indication that $\mathrm{CHA}$ may possess antimetastatic effect.

\section{CONCLUSION}

The results obtained in this study show that $\mathrm{CHA}$ inhibits the proliferation of_GC cells via the upregulation of miR-145expression and downregulation of $\mathrm{P} 13 \mathrm{~K} / \mathrm{Akt}$ signaling pathway.

\section{DECLARATIONS}

\section{Conflict of interest}

No conflict of interest is associated with this work.

\section{Contribution of authors}

We declare that this work was done by the authors named in this article and all liabilities pertaining to claims relating to the content of this article will be borne by the authors. SenMao Hu designed the study and wrote the manuscript. Shan Ping $\mathrm{Li}$ and SenMao $\mathrm{Hu}$ performed the experimental work, carried out the literature study and analyzed the data. The research article was thoroughly read by the authors before communication for the consideration of publication.

\section{Open Access}

This is an Open Access article that uses a funding model which does not charge readers or their institutions for access and distributed under the terms of the Creative Commons Attribution License (http://creativecommons.org/licenses/by/
4.0) and the Budapest Open Access Initiative (http://www.budapestopenaccessinitiative.org/rea d), which permit unrestricted use, distribution, and reproduction in any medium, provided the original work is properly credited.

\section{REFERENCES}

1. Ferlay J, Shin HR, Bray F, Forman D, Mathers C, Parkin $D M$. Estimates of worldwide burden of cancer in 2008: GLOBOCAN, 2008. Int J Cancer 2010; 127: 2893-2917.

2. Torre LA, Bray F, Siegel RL, Ferlay J, Lortet-Tieulent J, Jemal A. Global cancer statistics, 2012. CA Cancer J Clin 2015; 65: 87-108.

3. Xu AM, Huang L, Liu W, Gao S, Han WX, Wei ZJ. Neoadjuvant chemotherapy followed by surgery versus surgery alone for gastric carcinoma: Systematic review and meta-analysis of randomized controlled trials. PLOS One 2014; 9: e86941.

4. Xu AM, Huang $L$, Zhu L, Wei ZJ. Significance of peripheral neutrophil-lymphocyte ratio among gastric cancer patients and construction of a treatmentpredictive model: A study based on 1131 cases. Am J Cancer Res 2014; 4: 189-195

5. Ghosn M, Tabchi S, Kourie HR, Tehfe M. Metastatic gastric cancer treatment: Second line and beyond. World J Gastroenterol 2016; 22: 3069-3077.

6. Hammond SM. An overview of microRNAs. Adv Drug Deliv Rev 2015; 87: 3-14.

7. Miska EA. How microRNAs control cell division, differentiation and death. Curr Opin Genet Dev 2010; 15: 563-568.

8. Ueda $T$, Volinia $S$, Okumura $H$, Shimizu $M$, Taccioli $C$, Rossi S, Alder H, Liu CG, Oue N, Yasui W, et al. Relation between microRNA expression and progression and prognosis of gastric cancer: $A$ microRNA expression analysis. Lancet Oncol 2010; 11: 136-146.

9. Michael MZ, O'Connor SM, van Holst Pellekaan NG, Young GP, James RJ. Reduced accumulation of specific microRNAs in colorectal neoplasia. Mol Cancer Res 2003; 1: 882-891.

10. Hu J, Guo H, Li H, Liu Y, Liu J, Chen L, Zhang J, Zhang N. MiR-145 regulates epithelial to mesenchymal transition of breast cancer cells by targeting Oct4. PLOS One 2012; 7: e45965.

11. Wang F, Xia J, Wang N, Zong H. miR-145 inhibits proliferation and invasion of esophageal squamous cell carcinoma in part by targeting C-Myc. Onkologie 2013; 36: 754-758.

12. Lei C, Du F, Sun L, Li T, Li T, Min Y, Nie A, Wang X, Geng $L, L u Y$, et al. miR-143 and miR-145 inhibit gastric cancer cell migration and metastasis by suppressing MYO6. Cell Death Dis 2017; 8: e3101.

13. Qiu T, Zhou X, Wang J, Du Y, Xu J, Huang Z, Zhu W, Shu $Y$, Liu P. miR-145, miR-133A and miR-133b inhibit proliferation, migration, invasion and cell cycle 
progression via targeting transcription factor Sp1 in gastric cancer. FEBS Lett 2014; 588: 1168-1177.

14. Huang WJ, Wang YC, Chao SW, Yang CY, Chen LC, Lin MH, Hou WC, Chen MY, Lee TL, Yang P, Chang Cl. Synthesis and biological evaluation of ortho-aryl $\mathrm{N}$ hydroxycinnamides as potent histone deacetylase (HDAC) 8 isoform-selective inhibitors, ChemMedChem 2012; 7: 1815-1824.

15. Ai T, Xu Y, Qiu L, Geraghty RJ, Chen L. Hydroxamic acids block replication of hepatitis $C$ virus, $J$ Med Chem2015;58: 785-800.

16. Kozlov MV, Malikova AZ, Kamarova KA, Konduktorov $K A$, Kochetkov SN. Synthesis of pyridyl-4-oxysubstituted $N$-hydroxy amides of cinnamic acid as new inhibitors of histone deacetylase activity and hepatitis $C$ virus replication. Russ. J Bioorganic Chem2018;44: 453460.

17. Guimarães RM, Muzi CD. Trend of mortality rates for gastric cancer in Brazil and regions in the period of 30 years (1980-2009). Arq Gastroenterol 2012; 49: 184188.

18. Lima RT, Busacca S, Almeida GM, Gaudino G, Fennell $D A$, Vasconcelos $M H$. MicroRNA regulation of core apoptosis pathways in cancer. Eur J Cancer 2011; 47: 163-174.

19. Fulda S. Modulation of apoptosis by natural products for cancer therapy. Planta Med 2010; 76: 1075-1079.

20. Luo $X$, Burwinkel B, Tao S, Brenner H. MicroRNA signatures: Novel biomarker for colorectal cancer? Cancer Epidemiol Biomarkers Prev 2011; 20: 12721286.

21. Aksamitiene E, Kiyatkin A, Kholodenko BN. Cross-talk between mitogenic Ras/MAPK and survival PI3K/Akt pathways: A fine balance. Biochem Soc Trans 2012; 40: 139-146.

22. Hermeking $H$, Eick D. Mediation of c-Myc-induced apoptosis by p53. Science 1994; 265: 2091-2093.

23. Maclean $K H$, Keller UB, Rodriguez-Galindo $C$, Nilsson JA, Cleveland JL. C-Myc augments gamma irradiationinduced apoptosis by suppressing Bcl-XL. Mol Cell Biol 2003; 23: 7256-7270.

24. Shao Y, Qu Y, Dang S, Yao B, Ji M. MiR-145 inhibits oral squamous cell carcinoma (OSCC) cell growth by targeting c-Myc and Cdk6. Cancer Cell Int 2013; 13: 51.

25. Kessenbrock K, Plaks V, Werb Z. Matrix metalloproteinases: Regulators of the tumor microenvironment. Cell 2010; 141: 52-67. 